Jurnal Ilmu Sosial dan Pendidikan (JISIP)

Vol. 6, No. 1 Januari 2022

e-ISSN : 2656-6753, p-ISSN: 2598-9944

DOI: 10.36312/ jisip.v6i1.2763/http://ejournal.mandalanursa.org/index.php/JISIP/index

\title{
Kesesuaian Pengangkatan Pejabat Struktural Pada Pemerintah Kota Makassar
}

\author{
Arpin $^{1}$, Andi Agustang ${ }^{2}$ \\ ${ }^{1}$ Mahasiswa Program Studi Doktor Administrasi dan Kebijakan Publik, Universitas Negeri Makassar \\ ${ }^{2}$ Dosen Program Studi Doktor Sosiologi, Universitas Negeri Makassar
}

Article Info

Article history:

Received 27 Desember 2021

Publish 04 Januari 2022

\section{Keywords:}

First keyword

Second keyword

Third keyword

Fourth keyword

Fifth keyword

\begin{abstract}
ABSTRAK
Penelitian ini bertujuan untuk menjelaskan seberapa besar tingkat kesesuaian dan ketidaksesuaian pengangkatan pejabat struktural pada Pemerintah Kota Makassar. Penelitian ini bersifat deskriptif-kualitatif, metode analisis data yang dipergunakan dalam penelitian ini adalah tabulasi (tabel frekuensi), persentase dan kategorisasi dengan skala likert. Hasil penelitian mengindikasikan bahwa penelitian terhadap SK Walikota Makassar Nomor 4 Tahun 2002 tentang pengangkatan pegawai atau penempatan aparatur pada jabatan eselon II, eselon III eselon IV dalam lingkup organisasi Sekretariat Daerah Kota Makasssar ditemukan ketidaksesuaian dengan kriteria job spesification atau persyaratan jabatan. Hal yang sama juga diperoleh dar penilaian responden bahwa terdapat ketidak-sesuaian pengangkatan pejabat struktural dengan job spesification pada ketiga tingkatan jabatan eselon II, eselon III dan eselon IV. Secara keseluruhan, penilaian ketidak-sesuaian penempatan aparatur dalam jabatan dengan job spesification terutama terdapat pada persyaratan keahlian.

Demikian pula terhadap penilaian tingkat kemampuan sumber daya aparatur eselon II,eselon III, dan eselon IV dengan job spesification terdapat pada tingkat keahlian dan tingkat pendidikan. Penilaian keadaan penempatan sumber daya aparatur yang tidak sesuai menurut SK Walikota Makassar No. 4 Tahun 2001 dengan job spesification meliputi: keahlian dan golongan kepangkatan untuk eselon II, golongan kepangkatan dan keahlian untuk eselon III, golongan kepangkatan dan keahlian untuk eselon IV.Penilaian ketidak-sesuaian tingkat kemampuan dengan penempatan sumber daya aparatur dalam jabatan terdapat pada tingkat pendidikan, pelatihan, minat serta keahlian. Sedangkan penilaian ketidak-sesuaian tingkat kemampuan sumber daya aparatur dengan job spesification terhadap ketiga tingkatan eselon II, eselon III, dan eselon IV juga terdapat pada tingkat keahlian yang dimiliki.

Secara umum terdapat kesamaan antara penilaian responden dengan hasil analisis bukti-bukti sekunder mengenai penempatan dan kemampuan sumber daya aparatur dengan job spesification pada ketiga tingkatan jabatan eselon II, eselon III, dan eselon IV dalam lingkup organisasi Sekretariat Daerah Kota Makassar.

This is an open access article under the Lisensi Creative Commons AtribusiBerbagiSerupa 4.0 Internasional (ब) (1) (-)
\end{abstract}

Corresponding Author:

Arpin

Mahasiswa Program Studi Doktor Administrasi dan Kebijakan Publik, Universitas Negeri Makassar

Email: arpinnono@gmail.com

\section{PENDAHULUAN}

Sumber daya manusia yang memiliki kompetensi handal dari segala bidang dan apsek sangat ditentukan oleh kemampuan dasar intelektual yang dimiliki dalam menghadapi permasalahan-permasalahan dan perubahan eksternal maupun internal yang setiap saat bergerak semakin cepat dan semakin kompleks. Secara singkat, permasalahan yang sekarang dihadapi oleh birokrasi pemerintahan ialah : 1) kelembagaan birokrasi pemerintahan yang besar dan didukung oleh sumber daya aparatur yang kurang profesional; 2) mekanisme kerja yang sentralistik masih mewarnai kinerja birokrasi pemerintah; 3) kontrol terhadap birokrasi 
pemerintah dan dari pemerintah; 4) patron-klien (KKN) dalam birokrasi pemerintah merupakan halangan terhadap upaya mewujudkan meritokrasi dalam birokrasi; 5) tidak jelas dan bahkan cenderung tidak ada sense of accountability baik secara kelembagaan maupun secara individual; 6) jabatan birokrasi yang hanya menampung jabatan struktural dan pengisiannya tidak berdasarkan kompetensi yang dibutuhkan (BKN, 2000).

Untuk menerapkan sistem merit secara konsisten dalam pelaksanaan penempatan dan pemanfaatan PNS harus didasarkan pada standar jabatan dan kompetensi. Kedua standar tersebut dibuat berdasarkan hasil analisis jabatan dari organisasi yang bersangkutan.

Dari beberapa acuan pendayagunaan aparatur di atas, peranan analis jabatan semakin penting bagi pengembangan tingkat kemampuan aparatur melalui penempatan aparatur dalam jabatan sesuai job spesification (persyaratan jabatan) yang tepat atau lebih dikenal dengan istilah the right man on the right place.

Berdasarkan hasil penelitian PKDA I LAN Bandung (2003) telah merekomendasikan model pengembangan karir pegawai dalam rangka pemberdayaan sumber daya aparatur di daerah sebagai berikut:

"Wewenang promosi seharusnya diberikan kepada pimpinan daerah dan atau instansi dimana PNS tersebut bekerja, dengan pengecualian bahwa untuk pengembangan karir yang sifatnya lintas daerah, lintas lembaga serta untuk level (eselon) tertentu dilakukan oleh provinsi dengan pertimbangan dari komisi kepegawaian daerah, jika promosi dilakuan secara lintas atau antar provinsi dan untuk eselon tertentu maka pusatlah yang berwenang dengan pertimbangan dari komisi kepegawaian negara".

Hasil penelitian Jalis (2002) juga mengungkapkan bahwa:

"Memperlihatkan adanya kecenderungan angkatan kerja terbaik lebih menyukai bekerja pada sektor swasta ketimbang bekerja menjadi pegawai negeri sipil. Hal ini dapatlah dimaklumi dimana kondisi lembaga publik, umumnya bukan saja kurang menarik tetapi juga kurang kompetitif dilihat dari berbagai hal, seperti aspek gaji yang rendah, sistem karir yang kurang mempertimbangkan prestasi kerja, kondisi kerja yang kurang mendukung dan lain-lain".

Akibatnya, institusi layanan publik kurang memiliki daya inovasi yang memberikan inspirasi perubahan bagi masyarakat. Demikian halnya, masalah rapuhnya integritas dan rendahnya komitmen kerja terutama berawal dari kurang optimalnya penyeleksian pegawai yang berbasis pada aspek kompetensi, integritas, dan peminatan pegawai.

Beberapa faktor yang menjadi indikator dari job spesification (persyaratan jabatan) seperti pendidikan, pelatihan, pengetahuan, minat, pengalaman masa kerja, keahlian, dan kompetensi sangatlah penting diselaraskan dengan kemampuan aparatur dalam suatu organisasi unit kerja.

Kota Makassar sebagai salah satu daerah yang memiliki potensi dan peranan strategis di provinsi Sulawesi Selatan dalam proses kegiatan pembangunan dan pusat pemerintahan melalui organisasi pemerintahan daerahnya (Pemerintah Kota Makassar) dituntut untuk berpacu meningkatkan kualitas kinerja sumber daya manusia.

Akhir tahun 2005, Pemerintah Kota Makassar melakukan restrukturisasi kelembagaan, sehingga jumlah jabatan struktural menjadi berkurang khususnya pada jabatan eselon II dan eselon III dimana sebelumnya eselon II berjumlah 30 berkurang menjadi 24 serta eselon III yang sebelumnya berjumlah 182 mengalami pengurangan menjadi 121 jabatan. Seiring dengan semangat restrukturisasi kelembagaan di lingkungan Pemerintah Kota Makassar, Walikota Makassar sebagaimana dimuat Fajar (2005) secara gamblang mengutarakan bahwa:

"Dalam menjamin obyektivitas pengangkatan pejabat struktural khususnya pada jenjang jabatan eselon II dan III pasca rekstrukturisasi melalui proses selaksi yang benar-benar bersih dari unsur kolusi. Dengan demikian akan saya tunjuk lembaga independen yang profesional dalam bidang sumber daya manusia untuk melakukan asessment berdasarkan kompetensi”.

Komitmen Walikota Makassar untuk melakukan reogranisasi birokrasi pelayanan di lingkup Pemerintah Kota Makassar secara empirik terlihat dengan dilaksanakannya perekrutan PNS berdasarkan urutan kepangkatan yang dapat dipromosikan melalui metode asesment berdasarkan kompetensi. Namun, berbagai pendapat sentimentil beranggapan bahwa 
pengangkatan pejabat struktural pasca penerapan PP No. 8 Tahun 2003 tentang Pedoman Organisasi dan Tata Kerja Perangkat Daerah masih syarat dengan kepentingan, inefisiensi dalam arti pembiayaan APBD yang tidak perlu, dan ketidak profesionalitasnya instansi pelaksana termasuk pemeberian kesempatan kepada tim pemenang yang mengantakannya menjadi Walikota. Hal ini dielaborasi secara mendalam oleh Walikota Makassar sebagaimana termuat dalam bukunya yang berjudul Reorganisasi Birokrasi Pelayanan Publik (2006:2) bahwa:

"Banyak pihak yang mempertanyakan apa yang menjadi strategi saya dalam memimpin Pemerintah Kota Makassar, bahkan ada yang sampai menuding saya dan mencap bahwa tipe saya dalah tipe seorang pimpinan yang peragu. Banyak yang gemes, dan gregetan, pasalnya ketika awal-awal saya memangku jabatan, berselang beberapa hari, minggu-minggu pertama setelah saya dilantik banyak orang menunggu-nunggu, kapan mutasi dilakukan, mutasi yang biasa disebut penyusunan kabinet baru. Itu saya tidak terjadi, itu tidak saya lakukan. Mengapa demikian? Saya mempunyai alasan sendiri. Seiring dengan hal itu, saya sangat berhati-hati menerapkan aturan dan berusaha seobyektif mungkin, menangani reorganisasi kelembagaan pemerintah kota sebagaimana mestinya, tanpa harus dipengaruhi oleh pandangan subyektif yang bernuansa nepotisme".

Pelaksanaan rekruitmen pejabat struktural melalui metode asessment telah dilaksanakan oleh Walikota Makassar terhadap PNS yang menurut urutan kepangkatan dapat dipromosikan dalam jabatan-jabatan struktural merupakan

\section{LANDASAN TEORI}

\subsection{Konsep Managemen Sumber Daya Manusia}

Mondy dan Noe (1990:142) mendefinisikan manajemen sumber daya manusia sebagai aplikasi manajemen secara efektif dalam proses akusisi, pendayagunaan, pengembangan dan pemeliharaan personalia yang dimiliki suatu organisasi secara efektif untuk mencapai tingkat pendayagunaan sumber daya manusia yang optimal oleh organisasi tersebut dalam pencapaian tujuannya. Selanjutnya, Desller (1996:2231) dalam bukunya "Human Resources Management" menguraikan pengertian manajemen sumber daya manusia sebagai segala konsep dan teknik yang dibutuhkan untuk menangani aspek personalia dari sebuah posisi manajerial, seperti rekrutmen, seleksi, pelatihan, pemberian imbalan, dan penilaian kinerja.

Irawan (1997:15) menjelaskan bahwa aspek-aspek MSDM yang menyeluruh mencakup; 1) perencanaan SDM; 2) seleksi dan orientasi SDM; 3) pengembangan SDM; 4) manajemen karier; 5) penilaian prestasi kerja; 6) kompensasi; dan 7) pemutuhsan hubungan kerja. Ketujuh elemen MSDM saling bertalian satu sama lainnya dan memiliki interaksi yang cukup tinggi sehingga pembahasan terhadap suatu aspek tertentu harus didahului atau diikuti oleh pembahasan aspek lainnya. Senada dengan pendapat tersebut, Ruki (2003:17) mengemukakan terdapat beberapa program dan kegiatan yang berkaitan erat dengan manajemen sumber daya manusia yaitu: 1) perencanaan sumber daya manusia; 2) akusisi; 3) pengembangan; 4) pemberian imbalan dan ganjaran; dan 5) pengintegrasian.

Menurut Storey (1992:35) mencoba mengulas secara mendalam pengertian manajemen sumber daya manusia dan manajemen personalia, dimana ia menyatakan bahwa manajemen personalia memforkuskan pada input dan kegiatan atau program, sedangkan manajemen sumberdaya manusia memberi perhatian lebih pada output yaitu, sumber daya atau kekuatan yang dihasilkan oleh pegawai tersebut.

\subsection{Konsep Kompetensi}

Konsepsi kompetensi lahir tahun 1993 dan mulai populer di lingkungan perusahaan multinasional dan nasional yang modern. Wood \& Payne (1998:65) menyatakan kompetensi dipopulerkan oleh Rixhar Boyatzis, seorang penulis manajemen berkebangsaan Amarika Serikat melalui karyanya berjudul "The Competent Manager" pada tahun 1982. Spencer dan Spencer (1993:97) menyatakan kompetensi adalah an underliying chair of an individual tahat is casually related to criterion-referenced effective and/or superior performance in a 
job or situation". Artinya, karakteristik personality sangat berpengaruh besar terhadap tindakan sesorang menggeneralisasi segala situasi yang dihadai serta cenderung bertahan lama di diri orang tersebut. Lebih lanjut, Mitrani et.al (1992:46) menguraikan element yang membentuk kompetensi terdiri atas motif, karakter pribadi, konsep diri, pengetahuan dan skill. Pandangan Spencer dan Mitrani menekankan bahwa dalam menggunakan konsep kompetensi harus ada kriteria pembanding untuk membuktikan bahwa suatu elemen kompetensi mempengaruhi efektif tidaknya suatu hasil pekerjaan. Kompetensi yang tidak membuat perubahan dalam kinerja bukanlah suatu kompetensi dan tidak dapat dijadikan indikator untuk mengukur suatu hasil kerja seseorang.

Dalam paradigma manajemen modern, Ruki $(2003 ; 106)$ menyatakan bahwa kompetensi kaitannya dengan unjuk kerja dapat diklasifikasikan ke dalam dua jenis yakni, kompetensi ambang dan komptensi pembeda. Komptensi ambang menitikberatkan pada persyaratan minimal dan mendasar yang harus dipenuhi oleh sebuah jabatan dan harus dimiliki oleh pemangku jabatan agar dapat berkinerja tinggi dan produktif. Sedangkan, kompetensi pembeda merupakan elemen yang mengdiferensiasi antara orang yang berkinerja superior dan berkinerja rendah. Lebih lanjut, Ruki (2003) juga menjelaskan manfaat atau outcome yang dapat diperoleh melalui penerapan konsep kompetensi dalam organisasi yaitu: 1) memperjelas standar kerja dan harapan yang ingin dicapai; 2) alat seleksi karyawan; 3) memaksimalkan produktivitas; 4) dasar untuk pengembangan sistem remunerasi; 5) memudahkan adaptasi terhadap perubahan; dan 6) menyelaraskan perilaku kerja dan nilai-nilai organisasi.

\subsection{Pemanfaatan dan Pengembangan}

Dalam literatur kepegawaian, pemanfaatan dan pengembangan sering dipahami sebagai penempatan karyawan/pegawai. Siswanto (1987:23) menyatakan penempatan sebagai suatu prores pemberian tugas dan pekerjaan kepada tenaga kerja yang lulus seleksi untuk dilaksanakan secara terus menerus dengan wewenang dan tanggung jawab sebesar porsi dan komposisi yang ditetapkan, serta mampu mempertanggung jawabkan segala resiko dan kemungkinan yang terjadi atas tugas dan pekerjaan, wewenang dan tanggung jawab tersebut. Beberapa faktor yang perlu diperhatikan dalam penempatan kerja adalah kualifikasi pendidikan yang dimiliki, pengalaman, kesehatan fisik dan mental, status perkawinan dan usia (BKN, 2000:9). Komponen pemanfaatan dan penempatan kerja terdiri dari pengadaan, mutasi dan promosi jabawan.

Nitisemito (1996) menyatakan mutasi atau pemindahan adalah kegiatan pemindahan karyawan dari suatu pekerjaan ke pekerjaan lain yang dianggap setingkat atau sejajar. Mutasi atau rotas merupakan perpindahan jabawan yang merupakan upaya untuk memperluas pengalaman dan pengembangan bakar serta pembinaan karier setiap PNS yang dimana mutasi dapat dilakukan secara horizontal, vertikal dan diagonal.

Berbicara mutasi dan promosi, keduanya merupakan kegiatan perpindahan pegawai dari suatu jabatan kepada jabatan yang lain, meskipun keduanya dibedakan. Promosi adalah pemindahan pegawai dari suatu jabatan lain yang lebih tinggi (Nitisemito, 1996:81). Sejalan dengan hal tersebut, Moekijat (1999:101) mengartikan promosi adalah kemajuan seorang pegawai pada suatu tugas yang lebih baik, lebih baik dipandang dari sudut tanggung jawab yang lebih berat, martabat dan status yang lebih tinggi.

Dalam melakukan promosi, Nitisemito (1996:82) menyatakan bahwa terdapat beberapa syarat yang diperlukan untuk melakukan promosi pada jabatan tertentu antara lain: 1) pengalaman; 2) tingkat pendidikan; 3) loyalitas; 4) kejujuran; 5) tanggung jawab; 6) kepandaian bergaul; 7) prestasi kerja; dan 8) inisiatif dan kreatif.

Dalam pelaksanaan mutasi dan promosi, dikenal pula penerapan pendekatan asessment. Usmara (2002:80) menjelaskan asessment center sebagai suatu metoda penilaian yang digunakan untuk menilai dan mengevaluasi kapasitas sesorang secara komprehensif berdasarkan kriteria-kriteria tertentu yang ditetapkan secara sistematis dari hasil analisis pekerjaan, sehingga diharapkan mampu menggambarkan kriteria spesific sesuai yang 
dituntut oleh persyaratan jabatan yang ada. Metoda asessment berfokus pada perilaku dan memuat serangkaian latihan untuk menyadap dan mensimulasikan aspek-aspek, elemenelemen atau aktivitas-aktvitias utama jabatan yang menjadi sasaran (Prihadi, 2004:30).

Usmara (2002:69) dalam bukunya yang berjudul paradigma baru manajemen sumber daya manusia, secara tradisional asesment digunakan untuk: 1) menyeleksi orang-orang untuk pekerjaan lower dan middle management; 2) untuk penempatan; 3) pengembangan karier; 4) akreditasi; dan 5) untuk perencanaan karirer dan promosi. Dalam pelaksanaan asessment, Heneman (2001:525) menjelaskan elemen penilaian asessment yaitu; 1) oral communication; 2) planning and organizing; 3) delegation; 4) control; 5) decisiveness; 6) initiative; 7) toleransi for stress; 8) adaptability; dan 9) tenacity.

\section{METODE PENELITIAN}

Penelitian ini menggunakan jenis penelitian deksriptif kualitatif. Populasi dalam penelitian ini yaitu, seluruh PNS di lingkup Pemerintah Kota Makassar yang telah mengikuti assesment berbasis kompetensi. Penarikan sampel penelitian ini menggunakan teknik stratified sampling yaitu, para pejabat struktual mulai dari eselon II sampai dengan eselon IV, 1 orang mantan Asisten III Pemkab Maros, 2 orang anggota DPRD Kota Makassar dan 1 orang LSM mewakili masyarakat. Teknik pengumpulan data yang digunakan adalah kuesioner, wawancara dan studi dokumentasi. Untuk pengolahan data dan analisis data dalam penelitian ini menggunakan pendekatan dektiptif kualitatif dan analisis data tabulasi silang atau cross tabulation.

\section{HASIL DAN PEMBAHASAN}

Kesesuaian Kemampuan Pejabat Struktural dengan Job Spesification di lingkup Pemerintah Kota Makassar

\subsection{Hasil}

\section{Kesesuaiaan antara Kemampuan dengan Pengetahuan}

\section{a. Pejabat Eselon II}

Hasil kuesioner dari 100 responden diperoleh jawaban responden terhadap pernyataan yang diajukan tentang apakah penempatan aparatur dalam jabatan eselon II sudah sesuai dengan tingkat kemampuan pengetahuannya, diperoleh jawaban responden sebagaimana disajikan pada tabel .

\section{Tabel 1}

Tanggapan Responden Akan Kemampuan Eselon II Berdasarkan Pengetahuan

\begin{tabular}{|l|l|c|c|}
\hline No & $\begin{array}{l}\text { Kategori Penilaian } \\
\text { Responden }\end{array}$ & Frekuensi (f) & \% \\
\hline 1 & Sangat Sesuai & 36 & 36,0 \\
\hline 2 & Sesuai & 32 & 32,0 \\
\hline 3 & Cukup Sesuai & 24 & 24,0 \\
\hline 4 & Kurang Sesuai & 18 & 18,0 \\
\hline 5 & Tidak Sesuai & 8 & 8,0 \\
\hline Jumlah & 100 & 100,0 \\
\hline
\end{tabular}

Sumber: Hasil olahan data primer, 2006.

Tabel menunjukkan bahwa kecenderungan respon memberi jawaban cukup sesuai dengan frekuensi 36 atau 36\%. Hal ini berarti penempatan aparatur dalam jabatan eselon II dengan tingkat kemampuan pengetahuan yang dimiliki dinilai berjalan cukup sesuai.

Hal senada juga terungkap dari hasil wawancara penulis dengan Sekretaris Daerah Kota Makassar yang menyatakan bahwa dalam menempatkan aparatur pada posisi jabatan eselon II, unit organisasinya sudah mempertimbangkan tingkat pengetahuan pemangku jabatan yang bersangkutan disamping beberapa pertimbangan persyaratan jabatan lainnya di Sekretariat Daerah Kota Makassar. 


\section{b. Pejabat Eselon III}

Hasil kuesioner dari 100 responden diperoleh jawaban responden terhadap pertanyaan yang diajukan tentang apakah penempatan aparatur dalam jabatan eselon III sudah sesuai dengan tingkat kemampuan pengetahuannya. Diperoleh jawaban responden sebagaimana disajikan pada tabel

Tabel 2. Tanggapan Responden akan Kemampuan Eselon III Berdasarkan Pengetahuan

\begin{tabular}{|c|c|c|c|}
\hline No & $\begin{array}{c}\text { Kategori Penilaian } \\
\text { Responden }\end{array}$ & Frekuensi (f) & $\%$ \\
\hline 1 & Sangat Sesuai & 16 & 16,0 \\
\hline 2 & Sesuai & 24 & 24,0 \\
\hline 3 & Cukup Sesuai & 36 & 36,0 \\
\hline 4 & Kurang Sesuai & 14 & 14,0 \\
\hline 5 & Tidak Sesuai & 10 & 10,0 \\
\hline \multicolumn{2}{|c|}{ Jumlah } & 100 & 100,0 \\
\hline
\end{tabular}

Sumber: Hasil olahan data primer, 2006.

Tabel 2 menunjukkan kecenderungan responden memberi jawaban cukup sesuai dengan frekuensi 36 atau dengan persentase 36\%. Hal ini berarti penempatan aparatur dalam jabatan eselon III dengan tingkat kemampuan pengetahuan yang dimiliki dinilai berjalan cukup sesuai. Sejalan dengan temuan tersebut, hasil wawancara penulis dengan Sekretaris Daerah Kota Makassar juga mengungkapkan bahwa dalam menempatkan aparatur pada posisi jabatan eselon III, unit organisasinya sesuai dengan tingkat kemampuan pengetahuannya karena telah didukung oleh pendidikan dan golongan kepangkatan yang tinggi, senioritas masa kerja yang memadai, serta diklat kepemimpinan yang memadai khususnya dalam bidang tugasnya. Namun, juga dijelaskan bahwa pemangku jabatan eselon III yang belum sepenuhnya menguasai bidang tugasnya secara sempurna akibat baru menduduki jabatan barunya.

\section{c. Pejabat Eselon IV}

Berdasarkan hasil kuesioner dari 100 responden diperoleh jawaban responden terhadap pertanyaan yang diajukan tentang apakah penempatan pejabat eselon IV sudah sesuai dengan tingkat kemampuan pengetahuannya, diperoleh jawaban respon sebagaimana disajikan pada tabel 3.

Tabel 3. Tanggapan Responden akan Kemampuan Eselon IV Berdasarkan Pengetahuannya

\begin{tabular}{|l|l|c|c|}
\hline No & \multicolumn{1}{|c|}{$\begin{array}{c}\text { Kategori Penilaian } \\
\text { Responden }\end{array}$} & Frekuensi (f) & \% \\
\hline 1 & Sangat Sesuai & 16 & 16,0 \\
\hline 2 & Sesuai & 24 & 24,0 \\
\hline 3 & Cukup Sesuai & 36 & 36,0 \\
\hline 4 & Kurang Sesuai & 14 & 14,0 \\
\hline 5 & Tidak Sesuai & 10 & 10,0 \\
\hline Jumlah & 100 & 100,0 \\
\hline
\end{tabular}

Sumber: Hasil olahan data primer, 2006.

Tabel 3 menunjukkan kecenderungan responden memberi jawaban cukup sesuai dengan frekuensi 36 atau dengan persentase 36\%. Ini berarti penempatan eselon IV dengan tingkat kemampuan pengetahuan yang dimiliki dinilai berjalan cukup sesuai. Ungkapan senada juga terungkap dari hasil wawancara penulis dengan responden bahwa dirinya selalu berhubungan dengan pejabat eselon IV sehingga dapat mengetahui bahwa aparatur yang menempati jabatan eselon IV sudah memiliki wawasan pengetahuan yang luas, tingkat pendidikan dan golongan kepangkatan tergolong tinggi, pengalaman masa kerja yang mendukung penugasan bidang tugasnya serta diklat kepemimpinan yang memadai sehingga dinilai tingkat kemampuyan pengetahuan pejabat eselon IV berjalan cukup sesuai. 
Bertentangan dengan pernyataan di atas, hasil wawancara penulis dengan responden yang memberi jawaban tidak sesuai mengungkapkan bahwa dirinya jarang melakukan hubungan komunikasi dengan pejabat eselon IV dan tidak mengetahui latar belakang pendidikan dan pengalaman kerja pejabat eselon IV sehingga menilai penempatan ini berjalan tidak sesuai.

\section{Kesesuaian antara Kemampuan dengan Pengalaman Kerja}

\section{a. Pejabat Eselon II}

Berdasarkan hasil kuesioner dari 100 responden diperoleh jawaban responden terhadap pertanyaan yang diajukan tentang apakah penempatan aparatur dalam jabatan eselon II sudah sesuai dengan tingkat kemampuan pengalamannya, diperoleh jawaban responden sebagaimana disajikan pada tabel 4.

Tabel 4. Tanggapan Responden tentang Kesesuaian Kemampuan Berdasarkan Pengalaman

\begin{tabular}{|l|l|c|c|}
\hline No & $\begin{array}{c}\text { Kategori Penilaian } \\
\text { Responden }\end{array}$ & Frekuensi (f) & \% \\
\hline 1 & Sangat Sesuai & 20 & 20,0 \\
\hline 2 & Sesuai & 26 & 26,0 \\
\hline 3 & Cukup Sesuai & 38 & 38,0 \\
\hline 4 & Kurang Sesuai & 10 & 10,0 \\
\hline 5 & Tidak Sesuai & 6 & 6,0 \\
\hline Jumlah & 100 & 100.0 \\
\hline
\end{tabular}

Sumber: Hasil olahan data primer, 2006.

Tabel 4 menunjukkan kecenderungan responden memberi jawaban cukup sesuai dengan frekuensi 38 atau dengan persentase 38,0\%. Hal ini berarti penempatan sumber daya aparatur dalam jabatan eselon II dengan tingkat kemampuan pengalaman kerja yang dimiliki dinilai cukup sesuai. Relevan dengan hal tersebut dari hasil wawancara penulis dengan responden terungkap bahwa dirinya selalu berhubungan dengan pejabat eselon II baik dalam kapasitas hubungan kerja maupun hubungan pribadi sehingga dapat mengetahui bahwa aparatur yang menempati jabatan eselon II sudah memiliki wawasan pengalaman spesification yang penugasan bidang tugasnya serta diklat perjenjangan yang memadai sehingga dinilai tingkat kemampan pengalaman pejabat eselon II berjalan cukup sesuai.

\section{b. Pejabat Eselon III}

Berdasarkan hasil kuesioner dari 100 responden diperoleh jawaban terhadap pertanyaan yang diajukan tentang apakah penempatan aparatur dalam jabatan eselon III sudah sesuai dengan tingkat kemampuan pengalamanya, diperoleh jawaban responden sebagaimana terlihat pada tabel 5 berikut ini.

Tabel 5. Tanggapan Responden tentang Kesesuaian Kemampuan Berdasarkan Pengalaman

\begin{tabular}{|c|c|c|c|}
\hline No & $\begin{array}{c}\text { Kategori Penilaian } \\
\text { Responden }\end{array}$ & Frekuensi (f) & $\%$ \\
\hline 1 & Sangat Sesuai & 10 & 20,0 \\
\hline 2 & Sesuai & 13 & 26,0 \\
\hline 3 & Cukup Sesuai & 19 & 38,0 \\
\hline 4 & Kurang Sesuai & 6 & 10,0 \\
\hline 5 & Tidak Sesuai & 3 & 6,0 \\
\hline \multicolumn{2}{|c|}{ Jumlah } & 100 & 100.0 \\
\hline
\end{tabular}

Sumber: Hasil olahan data primer, 2006.

Tabel 5 di atas menunjukkan kecenderungan responden memberi jawaban cukup sesuai dengan frekuensi 19 atau dengan persentase 38,0\%. Hal ini berarti bahwa penempatan aparatur dalam jabatan eselon III dengan kemampuan pengalaman masa kerja yang dimiliki dinilai berjalan cukup sesuai. Selanjutnya, temuan penelitian ini juga didukung dari hasil wawancara penulis dengan responden yang mengungkapkan bahwa dirinya selalu berhubungan dengan pejabat eselon III baik dalam kapasitas hubungan 
kerja maupun hubungan pribadi sehingga dapat mengetahui bahwa aparatur yang menempat jabatan eselon III sudah memiliki wawasan dan pengalaman yang memadai, masa kerja lebih dari 10 tahun yang mendukung penguasaan bidang tugasnya. Serta diklat perjenjangan atau kepemimpinan yang memadai sehingga dinilai tingkat kemampuan pengalaman pejabat eselon III berjalan cukup sesuai.

Bersilangan dengan pernyataan di atas, hasil wawancara penulis dengan responden dengan jawaban yang tidak sesuai mengungkapkan bahwa dirinya jarang melakukan hubungan komunikasi dengan pejabat eselon III dan tidak mengetahui pengalaman masa kerja pejabat eselon III sehingga berjalan tidak sesuai.

c. Pejabat Eselon IV

Hasil penelitian terhadap 100 responden diperoleh jawaban responden terhadap pertanyaan yang diajukan tentang apakah penempatan pejabat eselon IV sudah sesuai dengan tingkat kemampuan pengalamannya, diperoleh jawaban responden sebagaimana disajikan pada tabel 6.

Tabel 6. Tanggapan Responden tentang Kesesuaian Kemampuan Berdasarkan Pengalaman

\begin{tabular}{|c|c|c|c|}
\hline No & $\begin{array}{c}\text { Kategori Penilaian } \\
\text { Responden }\end{array}$ & Frekuensi (f) & \% \\
\hline 1 & Sangat Sesuai & 10 & 20,0 \\
\hline 2 & Sesuai & 13 & 26,0 \\
\hline 3 & Cukup Sesuai & 19 & 38,0 \\
\hline 4 & Kurang Sesuai & 5 & 10,0 \\
\hline 5 & Tidak Sesuai & 3 & 6,0 \\
\hline \multicolumn{2}{|c|}{ Jumlah } & 100 & 100,0 \\
\hline
\end{tabular}

Sumber: Hasil olahan data primer, 2006.

Tabel 6 menunjukkan kecenderungan responden memberi jawaban cukup sesuai dengan frekuensi 19 dan persentese 38,0\%. Ini berarti penempatan aparatur dalam jabatan eselon IV dengan tingkat kemampuan pengalaman kerja yang dimiliki dinilai berjalan cukup sesuai. Senada dengan temuan penelitian tersebut, terungkap dari hasil wawancara penulis dengan responden menyatakan bahwa dirinya melihat aparatur yang menempati eselon IV sudah memiliki wawasan pengalaman kerja yang memadai dengan masa kerja lebih dari 10 tahun yang mendukung penguasaan bidang tugasnya sehingga dinilai tingkat kemampuan pengalaman kerja pejabat eselon IV berjalan cukup sesuai.

Bertentangan dengan pendapat di atas, hasil wawancara penulis dengan responden yang memberi jawaban tidak sesuai juga terungkap bahwa dirinya jarang melakukan hubungan komunikasi dengan pejabat eselon IV yang tidak mengetahui pengalaman masa kerja mereka sehingga berjalan tidak sesuai.

\section{Kesesuaian antara Kemampuan dengan Keahlian}

\section{a. Pejabat Eselon II}

Berdasarkan hasil kuesioner dari 100 responden diperoleh jawaban responden terhadap pertanyaan yang diajukan tentang apakah penempatan aparatur dalam jabatan eselon II sudah sesuai dengan tingkat kemampuan keahlian, diperoleh jawaban responden sebagaimana disajikan pada tabel 7.

Tabel 7. Tanggapan Responden atas Kemampuan Pejabat Eselon II Berdasarkan Keahlian

\begin{tabular}{|l|l|c|c|}
\hline No & $\begin{array}{c}\text { Kategori Penilaian } \\
\text { Responden }\end{array}$ & Frekuensi (f) & \% \\
\hline 1 & Sangat Sesuai & 14 & 14,0 \\
\hline 2 & Sesuai & 18 & 18,0 \\
\hline 3 & Cukup Sesuai & 22 & 22,0 \\
\hline 4 & Kurang Sesuai & 26 & 26,0 \\
\hline 5 & Tidak Sesuai & 20 & 20,0 \\
\hline Jumlah & 100 & 100,0 \\
\hline
\end{tabular}

Sumber: Hasil olahan data primer, 2006. 
Tabel 7 menunjukkan kecenderungan responden memberi jawaban kurang sesuai dengan frekuensi 26 atau persentas 26,0\%. Hal ini berarti penempatan sumber daya aparatur dalam jabatan eselon II dengan tingkat kemampuan kehalian yang dimiliki dinilai kurang sesuai. Senada dengan pendapat tersebut, hasil wawancara penulis dengan respondeng diungkapkan bahwa dirinya selalu berhubungan dengan pejabat eselon II baik dalam kapasitas hubungan kerja maupun hubungan pribadi sehingga dapat mengetahui bahwa aparatur yang menempati jabatan eselon II sudah memiliki wawasan pengalaman spesification yang penguasaan bidang tugasnya serta diklat perjenjangan yang memadai sehingga dinilai tingkat kemampuan keahlian pejabat eselon II berjalan kurang sesuai.

\section{b. Pejabat Eselon III}

Berdasarkan hasil kuesioner dari 100 responden diperoleh jawaban responden terhadap pertanyaan yang diajukan tentang apakah penempatan aparatur dalam jabatan eselon III sudah sesuai dengan tingak kemampuan keahlian diperoleh jawaban responden sebagaimana disajikan pada tabel 8 .

Tabel 8. Tanggapan Responden atas Kemampuan Pejabat Eselon III Berdasarkan Keahlian

\begin{tabular}{|c|c|c|c|}
\hline No & $\begin{array}{l}\text { Kategori Penilaian } \\
\text { Responden }\end{array}$ & Frekuensi (f) & $\%$ \\
\hline 1 & Sangat Sesuai & 14 & 14,0 \\
\hline 2 & Sesuai & 18 & 18,0 \\
\hline 3 & Cukup Sesuai & 22 & 22,0 \\
\hline 4 & Kurang Sesuai & 26 & 26,0 \\
\hline 5 & Tidak Sesuai & 20 & 20,0 \\
\hline & Jumlah & 100 & 100,0 \\
\hline
\end{tabular}

Sumber: Hasil olahan data primer, 2006.

Tabel 9 menunjukkan kecenderungan responden memberi jawaban kurang sesuai dengan frekuensi 26 atau dengan persentase 26,0\%. Hal ini berarti penempatan aparatur dalam jabatan eselon III dengan kemampuan pengalaman keahlian yang dimiliki dinilai berjalan kurang sesuai.

Senada dengan hal tersebut, dari hasil wawancara penulis dengan responden bahwa dirinya selalu berhubungan dengan pejabat eselon III baik dalam kapasitas hubungan kerja maupun hubungan pribadi sehingga dapat mengetahui bahwa aparatur yang menempati jabatan eselon III sudah memiliki wawasan dan pengalaman yang memadai, masa kerja lebih dari 10 tahun yang mendukung penguasaan bidang tugasnya, serta diklat perjenjangan atau kepemimpinan yang memadai sehingga dinilai tingkat kemampuan keahlian pejabat eselon III berjalan cukup sesuai.

Bersinggungan dengan pendapat di atas, hasil wawancara penulis dengan responden dengan jawaban tidak sesuai mengungkapkan bahwa dirinya jarang melakukan hubungan komunikasi dengan pejabat eselon III dan tidak mengetahui kemampuan keahlian pejabat eselon III sehingga berjalan tidak sesuai.

c. Pejabat Eselon IV

Hasil kuesioner dari 100 responden diperoleh jawaban responden terhadap pertanyaan yang diajukan tentang apakah penempatan pejabat eselon IV sudah sesuai dengan tingkat kemampuan keahlian, diperoleh jawaban responden sebagaimana disajikan pada tabel 9.

Tabel 9. Tanggapan Responden atas Kemampuan Pejabat Eselon IV Berdasarkan Keahlian

\begin{tabular}{|l|l|c|c|}
\hline No & \multicolumn{1}{|c|}{$\begin{array}{c}\text { Kategori Penilaian } \\
\text { Responden }\end{array}$} & Frekuensi (f) & \% \\
\hline 1 & Sangat Sesuai & 14 & 14,0 \\
\hline 2 & Sesuai & 18 & 18,0 \\
\hline 3 & Cukup Sesuai & 22 & 22,0 \\
\hline 4 & Kurang Sesuai & 26 & 26,0 \\
\hline 5 & Tidak Sesuai & 20 & 20,0 \\
\hline
\end{tabular}




\begin{tabular}{|l|c|c|}
\hline Jumlah & 100 & 100,0 \\
\hline
\end{tabular}

Sumber: Hasil olahan data primer, 2006.

Tabel 9 menunjukkan kecenderungan responden memberi jawaban kurang sesuai dengan frekuensi 26 atau dengan persentase $26 \%$ penempatan aparatur dalam jabatan eselon IV dengan tingkat kemampuan keahlian dinilai berjalan kurang sesuai.

Temuan penelitian ini juga dikuatkan dari hasil wawancara penulis dengan responden yang menegaskan bahwa dirinya jarang melakukan hubungan komunikasi dengan pejabat eselon IV yang tidak mengetahui keahlian mereka sehingga berjalan kurang sesuai. Sementara itu, hasil wawancara penulis dengan informan lain menyatakan bahwa penempatan aparatur pada posisi jabatan eselon IV umumnya kurang sesuai dengan tingkat kemampuan keahlian karena terbatasnya SDM yang akan menempati sejumlah jabatan pemerintahan. Namun juga dijelaskan bahwa masih terdapat pejabat eselon IV yang tidak memahami tugas pokok dan fungsinya karena baru menduduki jabatan struktural eselon IV tersebut.

\subsection{Pembahasan}

Bertitik tolak dari Keputusan Walikota Makasasr Nomor 646/KP/800/2004 tanggal 1 November 2004 tentang syarat jabatan bagi pengangkatan pejabat struktural lingkup pemerintah daerah kota Makassar dilakukan analiss terhadap pejabat-pejabat yang telah menduduki jabatan struktural pada berbagai tingkatan eselon di Sekretariat Daerah Kota Makassar yang terdiri dari pejabat eselon II, eselon III dan eselon IV.

\section{Hasil Analisis Data Sekunder \\ a. Eselon II}

Hasil analisis pejabat eselon II atas kesesuaian dengan syarat jabatan khususnya mengenai pendidikan formal, semuanya telah memenuhi syarat. Demikian pula diklat jabatan dari ke empat pejabat tersebut semuanya telah mengikuti diklat kepemimpinan tigkat II. Dari pengalaman jabatan juga menunjukkan telah banyaknya jabatan-jabatan yang telah diduduki sebelumnya, sehingga dianggap sangat berpengalaman dalam mengemban tugas pokok dan fungsi dari jabatan tersebut.

\section{b. Eselon III}

Secara keseluruhan jumlah jabatan pada jenjang eselon III sebanyak 11 (sebelas) dari sekian jabatan tersebut terdapat satu pejabat yang tidak berkesesuaian dengan persyaratan promosi, yang mana bagi pejabat yang dipromosikan pada jabatan eselon III seharusnya telah pernah menduduki jabatan eselon IV. Demikian halnya mengenai diklat kepemimpinan yang telah diikuti hanya diklat kepemimpinan tingkat IV, meskipun ketentuan untuk itu memberi kelonggaran untuk diikuti setelah pejabat tersebut menduduki jabatan eselon III.

\section{c. Eselon IV}

Demikian halnya dengan jabatan struktural eselon IV yang berjumlah 32 (tiga puluh dua), setelah dilakukan analisis terhadap kesesuaian dengan syarat jabatan ditemukan ketidaksesuaian antara lain jenjang pendidikan 1 orang tidak memenuhi syarat, untuk diklat kepemimpinan terdapat 1 orang yang belum pernah mengikuti diklat, untuk masa kerja semua pejabat struktural eselon IV telah memenuhi syarat. Sedangkan, syarat keahlian terdapat 10 pejabat yang tidak berkesesuaian dan untuk syarat kepangkatan juga terdapat 2 orang yang tidak berkesesuaian. Rekapitulasi tingkat kesesuaian untuk level eselon ini 94\% sesuai dengan hanya $6 \%$ yang tidak sesuai.

\section{Hasil Analisis Data Primer}

Hasil analisis data primer yang bersumber dari tanggapan responden atas kemampuan yang didasarkan atas keahlian, kemampuan yang didasrkan atas pengetahuan dan kemampuan yang didasarkan atas pengalaman jabatan. Dari 100 responden yang menjadi sampal penelitian ini diperoleh tanggapan sebagai berikut: 
a. Kemampuan berdasarkan pengetahuan. Terdapat 16\% menyatakan sangat sesuai, $24 \%$ menyatakan sesuai, 36\% menyatakan cukup sesuai, 14\% yang menyatakan kurang sesuai dan hanya $10 \%$ menyatakan tidak sesuai.

b. Kemampuan berdasarkan pegalaman kerja responden yang menyatakan sangat sesuai $20 \%$, yang menyatakan sesuai $26 \%$, cukup sesuai $38 \%$, kurang sesuai $10 \%$ dan hanya $6 \%$ yang menyatakan tidak sesuai.

c. Kemampuan berdasrkan keahlian terdapat $14 \%$ menyatakan sangat sesuai, $18 \%$ sesuai, $22 \%$ cukup sesuai, $25 \%$ menyatakan kurang sesuai dan terdapat $20 \%$ menyatakan tidak sesuai. Ketiga variabel tersebut responden yang menanggapi tidak sesuai terbanyak pada penilaian atas kemampuan yang didasarkan keahlian.

\section{KESIMPULAN}

Pada dasarnya proses asessment yang telah dilakukan oleh pemerintah kota makassar bertumpu pada konsep direct simulation dengan kata lain jantung sebuah asessment adalah terletak pada latihan-latihan simulasi. Para pengguna metode asessment memperoleh informasi yang akurat, andal dan komprehensif mengena taraf kemampuan kritis sumber daya aparatur yang dimiliki organisasi melalui serangkaian proses dan seperangkat kombinasi metode pengukuran yang canggih.

Hasil penelitian ini dapat disimpulkan bahwa terdapat kesesuaian antara pengangkatan pejabat struktural dengan persyaratan yang ditetapkan dengan Peraturan Pemerintah Nomor 100 Tahun 1999 yang diperbaharui dengan Peraturan Pemerintah Nomor 14 Tahun 2003 dan Keputusan Walikota Makassar Nomor 646/KP/600/2004 tangal 1 November 2004 tentang syarat jabatan bagi pengangkatan pejabat struktural. Dimana:

\section{a. Pengangkatan pejabat Eselon II}

Pada umumnya semua syarat jabatan telah dipenuhi pada pengkatan pejabat untuk jabatan ini, yang tidak sesuai terdapat pada bidang pengetahuan sebanyak $8 \%, 6 \%$ untuk pengalaman kerja dan $20 \%$ yang tidak sesuai bidang keahlian.

\section{b. Pengangkatan pejabat Eselon III}

Pada umumnya semua syarat jabatan telah dipenuhi pada pengangkatan pejabat pada jenjang jabatan ini, namun masih terdapat $6 \%$ tidak berkesesuaian menyangkut pengalaman kerja, 20\% untuk keahlian, sedangkan untuk pengetahuan terdapat $10 \%$ yang tidak sesuai.

\section{c. Pengangkatan pejabat Eselon IV}

Pada umumnya pengangkatan pejabat struktural eselon IV telah memenuhi syarat jabatan, yang masih belum sesuai antara lain 10\% mengenai pengetahuan, $6 \%$ mengenai pengalaman kerja, dan untuk bidang keahlian terdapat $20 \%$ yang tidak sesuai.

\section{SARAN}

Berangkat dari temuan dan pembahasan hasil penelitian, maka dikemukakan saran sebagai berikut:

a. Kesesuaian akan syarat jabaan bagi pejabat yang telah diangkat hendaknya diikuti pada pengangkatan pejabat struktural lainnya.

b. Jika terjadi mutasi, rotasi atau promosi pejabat hendaknya disesuaiakan dengan bidang keahlian yang dimiliki.

c. Hendaknya Badan Pertimbangan Jabatan dan Kepangkatan lebih konsisten memberlakukan syarat jabatan bilamana akan merekrut calon pejabat struktural.

d. Terhadap pejabat yang belum memenuhi kesesuaian dengan syarat jabatan sepenuhnya, kiranya menjadi pencermatan untuk tidak terulang perekrutan selanjutnya.

\section{DAFTAR PUSTAKA}

Abidin. 2000. Pegawai Sebagai Sumber Daya Manusia. Yogyakarta: Andi.

Arikunto, S. 1991. Prosedur Penelitian Suatu Pendekatan. Jakarta: Rineka Cipta.

Bernaddin, H, J. Dan Russelm JE, A. 1993. Human Resources Management an Exprimental Approach, International Edition. McGraw, Inc. 
Badan Kepegawaian Negara. 1992. Asessment Center Bagi PNS Tahun 2002. Jakarata: Puslitbang BKN.

2002. Peta Potensi Kepegawaian (Kasus Guru di Tiga Propinsi. Jakarta: Puslitbang BKN.

Dessler, Gary. 1996. Human Resources Management. Englewood Cliffs $\mathrm{Nj}$. Prentice Hall International.

Dewan Perwakilan Rayat Daerah Kota Makassar. 2005. Laporan Pertanggung Jawaban Walikota Makassar. Makassar: Sekretariat DPRD.

Erkaningrum, F, Indri. 2002. The Boundaryless Career pada Abad Ke-21. Yogyakarta: Amara Books.

Fajar, Harian. 2005. Kolom Makassar Metro, 15 Desember 2005. Makassar: Percetakan Fajar.

Gatewood, D. 2001. Employee Training and Development, Illniors, Richard D. Irwin, Inc.

Handoko, T, Hani. 1987. Manajemen Personalia dan Sumber Daya Manusia, Edisi 2. Yogyakarta: BPEE.

Hasibuan, SP. Malayu. 1999. Manajemen Sumber Daya Manusia. Jakarta: Gunung Agung.

Heneman, Herbert, G. 2001. Staffing Organizations, 3 rd ed., USA: McGraw-Hill.

Irawan, Prasetya. 1997. Manajemen Sumber Daya Manusia. Jakarta: STIA-LAN Press.

Jalis, MA. 2002. Assesment Center Bagi PNS Tahun 2002. Jakarta: Badan Kepegawaian Negara.

Klemp. 1980. Personnel Management, edisi kelima. Singapore: McGraw-Hill.

Keputusam Walikota Makassar Nomor: 646/KP/800/2004 Tanggal 1 Nopember 2005 tentang Syarat bagi Jabaan Struktural pada Sekretariat Daerah Kota Makassar.

Mitrani, A, Daziel., and Fitt, D. 1992. Competency Based Human Resources Management, Value-Driven Strategies for Recruitmen, Development and Reward. London: Kogan Page Limited.

Mondy, RW., dan Noe, RM. 1990. Human Resources Management 4 thEdition. USA: Allyn and Bacon.

Moekijat. 1999. Manajemen Sumber Daya Manusia (Manajemen Kepegawaian). Bandung: Mandar Maju.

Musanef. 2000. Manajemen Kepegawaian. Jakarta: H. Aras Agung.

Nitisemito, S. Alex. 1996. Manajemen Personalia (Manajemen Sumber Daya Manusia). Kudus: Ghalia Indonesia.

Peraturan Pemerintah Nomor 101 Tahun 2000 tentang Pendidikan dan Pelatihan Jabatan pegawai Negeri Sipil.

Peraturan Pemerintah Nomor 8 Tahun 2003 tentang Pedoman Struktur Organisasi dan Tata Kerja Pemerintah Daerah.

Peraturan Pemerintah Nomor 13 Tahun 2002 tentang Pengangkatan dalam Jabatan Struktural.

Peraturan Walikota Makassar Nomor 4 Tahun 2005 tentang Uraian Tugas dan Fungsi Sekretariat Daerah Kota Makassar.

Peraturan Walikota Makassar Nomor 50 Tahun 2005 tentang Tugas Pokok dan Fungsi Sub Bagian pada Sekretariat Daerah Kota Makassar.

Prihadi, Syaiful, F. 2004. Assesment Centre (Identifikasi, Pengukuran, dan Pengembangan Kompetensi). Jakarta: Gramedia Pustaka Utama.

Pusat Kajian dan Diklat Aparatur I LAN. 2005. Pemberdayaan Sumber Daya Aparatur dalam Pelaksanaan Otonomi Daerah. Bandung: PKDA I LAN.

Rapat Teknis Nasional Kepegawaian. 2004. Program Implementasi Kebijakan Kepegawaian Dalam Rangka Meningkatkan Profesionalisme dan Netralitas PNS.

Struktural. Jakarta: Badan Kepegawaian Negara.

.2005. Program Kebijakan Pengangkatan Pejabat

Robert, D. Hubert S, Filed. 2001. Human Resources Selection 5 thed. Harcourt, Inc.

Ruky, S.H. Achmad. 2003. SDM Berkualitas (Mengubah Visi menjadi Realitas). Jakarta: Gramedia Pustaka Utama. 
SANKRI. 2003. Sistem Administrasi Negara Kesatuan Republik Indonesia. Jakarta: Lembaga Administrasi Negara.

Sarundajang, S.H. 1999. Arus Balik Kekuasaan Pusat ke Daerah. Jakarta: Pustaka Sinar Harapan.

Saydam. 1996. Kebudayaan, Mentalitas, dan Pembangunan. Jakarta: Grameda Pustaka Utama.

Sirajuddin, Ilham, Arief. 2006. Reorganisasi Birokrasi Pelayanan Publik (Suatu Tinjauan Strategi Membangun Makassar dari Dalam). Makassar: Hasanuddin University Press.

Simamora, Henri. 1997. Manajemen Sumber Daya Manusia. Yogyakarta: BPSTIE YPKN.

Siswanto, B. 1987. Manajemen Tenaga Kerja, Cetakan Kedua. Bandung: Sinar Baru.

Snebecker, Glenn E. 1974. Learning Theory and Psychoeducational Design. New York: Mc Graw-Hill Book Company.

Spencer, Lyle, M dan Spencer, Sgne M. 1993. Competence at Work. New York: John Wiley \& Sons, Inc.

1989.Teori Motivasi dan Aplikasi. Jakarta: Penerbit Bina Aksara.

Storey, John. 1992. Development of The Management of Human Resources. Oxford: Blackwell Publisher.

Tilaar, H.A.R. 1997. Pengembangan Sumber Daya Manusia dalam Era Globalisasi: Visi, Misi dan Program Aksi Pendidikan dan Pelatihan Menuju 2002. Jakarta: PT. Gramedia Widiasarana Indonesia.

Undang-Undang Nomor 43 Tahun 1999 perubahan atas Undang-Undang Nomor 8 Tahun 1974 tentang Pokok-Pokok Kepegawaian.

Undang-Undang Nomor 32 Tahun 2004 tentang Pemerintahan Daerah.

Usmara, A. 2002. Paradigma Baru Manajemen Sumber Daya Manusia, Edisi Kedua. Yogyakarta: Amara Books.

Wood Robert adn Payne, Tim. 1996. Competency Based Recruitment and Selection, Apratical Guide 1st Edition. England: John Wiley \& Sons.

Woodruffe, C. 1994. Assesment Centres. London: Institut of Personal Management. 